\title{
Demographic Faultlines in Groups: The Curvilinearly Moderating Effects of Task Interdependence
}

\author{
Youngjin KWON*, Junyeong LEE ${ }^{* *}$
}

Received: January 28, 2020 Revised: February 9, 2020 Accepted: February 11, 2020.

\begin{abstract}
This study aims to examine curvilinearly moderating effects of task interdependence on the relationship between demographic faultlines and group performance. It posits that the degree of task interdependence has an impact on the effects of demographic faultlines. It was conducted in six organizations in Korea, their industries including heavy industries, hospital, construction, petrochemical, fine chemicals, and system integration. The survey was distributed to 1330 individuals in 162 teams and 1082 individuals in 137 teams responded to the questionnaire. To test the hypotheses including nonlinear interactions, we conducted a hierarchical regression analysis to the survey data from 82 groups within six firms in Korea. The results show that for groups that experience a high level of task interdependence, the slope for the regression of demographic faultlines on group performance is comparatively low and, at the low level of task interdependence, insignificant. However, at intermediate levels of task interdependence, the association was strongly negative and significant. This study finds that the negative relationship between demographic faultlines and group performance is stronger when task interdependence is moderate than when task interdependence is high or low. Therefore, managers should pay attention to optimal group design by carefully assigning tasks in diverse and divided groups.
\end{abstract}

Keywords : Task Interdependence, Demographic Faultlines, Group Performance, Curvilinear Moderation, Korean Firm

JEL Classification Code: D20, D23, M12, M54.

\section{Introduction}

Theoretically extending the research on diversity (O'Reilly, Caldwell, \& Barnett, 1989), Lau and Murnighan (1998) proposed the concept of faultines that split the groups into subgroups based on the alignment of two or more individual attributes. Because faultlines have higher explanatory power than does those of group demography variables (Thatcher \& Patel, 2011), interest in faultlines has burgeoned for the past two decades. For instance, strong faultlines negatively influence group learning (Gibson \&

*First Author. Ph.D. Student, Fox School of Business, Temple University, Philadelphia, PA, USA.

Email: youngjin.kwon@temple.edu

${ }^{* *}$ Corresponding Author. Assistant Professor, School of Industrial Management, Korea University of Technology and Education (KoreaTech), Republic of Korea. [Postal Address: 1600 Chungjeolro, Byeongcheon-myeon, Dongnam-gu, Cheonan-si, Chungcheong nam-do, 31253 Korea] Tel.: +82-41-560-1421, Fax.: +82-41-5601439, Email: junyeong_lee@koreatech.ac.kr

(c) Copyright: The Author(s)

This is an Open Access article distributed under the terms of the Creative Commons Attribution NonCommercial License (https://creativecommons.org/licenses/by-nc/4.0/) which permits unrestricted noncommercial use, distribution, and reproduction in any medium, provided the original work is properly cited.
Vermeulen, 2003; Lau \& Murnighan, 2005), intrateam conflict (Thatcher, Jehn, \& Zanutto, 2003), group functioning (Molleman, 2005) as well as group performance (Jehn \& Bezrukova, 2010; van Knippenberg, Dawson, West, \& Homan, 2011). Faultlines conceptually include non-demographic attributes such as abilities and personalities (Molleman, 2005). In general, however, faultines researchers have focused on the demographic attributes such as race, age, gender, functional background (Thatcher \& Patel, 2011). This study focuses on the demographic faultines based on demographic attributes involving age, gender, and tenure.

While empirical studies have demonstrated the negative impacts of faultlines, some empirical studies, as those on diversity, have examined the contingent effects of faultlines (Na, Park, \& Kwak, 2018; Thatcher \& Patel, 2012) to define their boundary conditions. One of the notable suggestions regarding the contingencies is the salience of subgroups (van Knippenberg, De Dreu, \& Homan, 2004). The salience of subgroups refers to the degree to which subgroup identities are salient to group members. Teams with higher levels of faultlines strength are more likely to 
have salient subgroup identities because of the alignment of two or more attributes, but the strong faultines do not always guarantee salience of subgroups. For example, van Knippenberg et al. (2011) has shown that, even though top management teams have strong faultlines, shared goals decrease the salience of subgroups, attenuating the negative impacts of faultlines.

This study suggests that task interdependence, the degree to which members work interdependently with each other (Kiggundu, 1983), might be one potential factor that affects the salience of subgroups within groups, thereby changing the effects of demographic faultlines. Team design researchers have regarded task interdependence as an important feature of team design (Kozlowski \& Bell, 2003), and have proved that task interdependence affects diverse group functioning pertaining to tasks and relations (Courtright, Thurgood, Stewart, \& Pierotti, 2015). Because intense task interdependence provides the need for collaboration (Lam \& Chin, 2004) and determine the degree of interactions within groups (Stewart \& Barrick, 2000), previous studies have demonstrated that task interdependence moderates the relationships between diversity and group outcomes (Joshi \& Roh, 2009; Van der Vegt \& Janssen, 2003). Thus, this study draws from the literature on faultlines, diversity, and task interdependence to argue that the levels of task interdependence influence the negative relationship between demographic faultlines and group performance by exacerbating or alleviating the salience of subgroups.

Accordingly, the objectives of this study are as follows. First, the study reviews existing literature on faultlines, diversity, and task interdependence. Then, the study hypothesizes that the degree to which group members are interdependent on each other curvilinearly, or nonlinearly, moderates the negative relationship between demographic faultlines and group performance. Second, the study proves the hypothesis using hierarchical regression analysis with 82 teams in six Korean firms. Finally, the study discusses and addresses the theoretical contributions, limitations, and implications for future research of this study.

\section{Literature Review and Hypothesis}

\subsection{Faultlines}

Faultlines are defined as "hypothetical dividing lines that may split a group into two or more subgroups based on one or more individual attributes" (Lau \& Murnighan, 1998, p.328). For example, suppose that there are two teams, each of which consists of 6 members. Team A consists of three white males and three Asian females. On the contrary, team B is composed of two white and one Asian males, and one white and two Asian females. Though gender diversity and racial diversity of the two teams are same, team A holds a stronger faultline than team B because of the alignment of two demographic categories, gender, and race. In other words, team A is more likely to be divided into two homogenous subgroups than team B.

With its theoretical roots on social identity theory (Tajfel, 1978) and self-categorization theory (Turner, 1982), faultlines have been found to influence a host of outcomes including group processes and group performances. Groups with stronger faultlines are more likely to suffer from greater task conflict, relationship conflict, and process conflict (Bezrukova, Thatcher, \& Jehn, 2007; Li \& Hambrick, 2005; Thatcher et al., 2003). In addition, faultlines negatively affect group respect and liking (Cronin, Bezrukova, Weingart, \& Tinsley, 2011; Molleman, 2005), team satisfaction (Rico, Molleman, SánchezManzanares, \& Van der Vegt, 2007), team psychological safety (Lau \& Murnighan, 2005), team cohesion (Lau \& Murnighan, 2005), group learning (Gibson \& Vermeulen, 2003), and group performance (Homan, Hollenbeck, Humphrey, van Knippenberg, Ilgen, \& van Kleef, 2008; Jehn \& Bezrukova, 2010). Thatcher and Patel (2011)'s recent meta-analysis on faultlines has comprehensively confirmed the negative impact of faultines on several outcomes: faultines have positive association with task conflict $(\rho=0.06)$, relationship conflict $(\rho=0.05)$ and negative association with team cohesion $(\rho=-0.06)$, team satisfaction $(\rho=-0.15)$, and team performance $(\rho=-0.55)$.

Despite the negative impacts of faultlines on intragroup processes and outcomes, the negative relationship between faultlines and outcomes depends on the diverse contexts. For example, Cooper, Patel, and Thatcher (2014) found that the environmental contexts of corporations moderate the association between informational faultines faultlines based on informational attributes such as tenure and functional background - and top management team performance. Bezrukova, Jehn, Zanutto, and Thatcher (2009) also demonstrated that groups with strong faultlines benefit from high levels of team identification. Indeed, according to a recent meta-analysis of diversity (Joshi \& Roh, 2009), the relationship between diversity and outcome varies depending on team-, industry-, and occupation-level contexts, implying the importance of moderating approaches to diversity and faultline research.

One of the key factors vis-à-vis the contingency is the salience of subgroups (Turner, Hogg, Oakes, Reicher, \& Wetherell, 1987; van Knippenberg et al., 2004), the degree to which subgroups are salient to the group members. When the subgroups identities are salient among group members, group members are more likely to have insubgroup categorization, favoritism and identification, and 
out-subgroup bias (Gaertner, Dovidio, Anastasio, Bachman, \& Rust, 1993; Gaertner, Mann, Murrell, \& Dovidio, 1989). Thus, if the subgroups' identities are not salient to the group members, group members are less likely to perceive subgroup split in their groups and faultines may not come into action. In other words, even though the groups have high values in faultlines, groups do not certainly have active faultlines (Jehn \& Bezrukova, 2010). In this vein, van Knippenberg et al. (2011) has shown that shared objectives attenuate the negative impacts of faultlines by developing the salience of categorization as one team and rendering subgroups less salient. However, existing studies on faultlines have generally focused on only one antecedent of the salience of subgroups, the degree of faultlines (van Knippenberg et al., 2011), and it might distort and connive the true effects of subgroup salience and faultlines. Thus, investigating the factors that additionally influence the salience of subgroups in groups might provide additional insight into the research on subgroups and faultlines.

\subsection{Task Interdependence and Demographic Faultlines}

One potential factor that might influence the salience of subgroup and moderate the negative relationship between demographic faultlines and outcomes is task interdependence. Task interdependence is defined as the extent to which group members have to depend on each other to complete jobs (Campion, Medsker, \& Higgs, 1993; Kiggundu, 1983). Because the level of task interdependence determines the interpersonal interaction (Johnson \& Johnson, 1989), coordination (Guzzo \& Shea, 1992), and experienced responsibility for others' activities (Pearce \& Gregersen, 1991), task interdependence has been regarded as one of the important factors in team design research (Kozlowski \& Bell, 2003). Drawing from the existing literature, this study suggests that task interdependence would curvilinearly moderate the negative relationship between demographic faultlines and group performance.

First of all, when group members are low task interdependent, group members have only limited interactions with others to complete the task. Rather, each group member works as an individual with little need to share knowledge and resources (Gibson, 1999). Under such circumstances, each individual's responsibility is comparatively identifiable (Stewart \& Barrick, 2000), reducing the members' subjective uncertainty experienced in groups (Van der Vegt \& Janssen, 2003). Reduced uncertainty, in turn, prevents the categorization process from taking place (Hogg \& Terry, 2000). Thus, categories of members are less valued and meaningful, meaning that subgroups are less salient even in groups with strong demographic faultlines. In this aspect, groups with low interdependence are less likely to suffer from conflict (Saavedra, Earley, \& Van Dyne, 1993). Furthermore, even if strong demographic faultlines divide groups with low interdependence into subgroups, groups would not be seriously damaged because group members do not need to depend much on others' knowledge and expertise to perform their tasks. All things considered, this study predicts that the negative effects of demographic faultlines on group performance weaken in teams with low interdependence.

When team members are highly task-interdependent, this study also expects that the negative relationship between demographic faultlines and group performance attenuates. Numerous studies have documented that task interdependence fosters the environment for communication and cooperation. For example, high task interdependence offers an incentive for collaboration (Lam \& Chin, 2004), increases members' sense of responsibility (Pearce \& Gregersen, 1991), develops norms of cooperation (Shaw, 1981), and need for coordination (Anderson \& Williams, 1996). Thus, groups with a higher level of task interdependence could achieve open communication of good quality (Courtright et al., 2015; Stewart \& Barrick, 2000; Thompson, 1967).

The increase in cooperative and open communication, in turn, leads to a decrease in the salience of subgroups in groups even with strong demographic faultlines. For example, contact hypothesis suggests that cooperative contacts reduce bias and produce favorable attitudes toward outgroups (Pettigrew, 1998; Sherif, Harvey, White, Hood, \& Sherif, 1961). Furthermore, the high quality of interpersonal interaction arising from a high level of task interdependence (Johnson \& Johnson, 1989) would encourage members to form not categorical, but individualized impressions of outgroup members. Thus, when a group has strong demographic faultlines, but members in the group are highly task interdependent, they are less likely to see dissimilar members as out-group, reducing outgroup biases and stereotyping. In support of this argument, Jehn and her colleagues found that the relationship between demographic diversity and workgroup performance is positive when workgroups are interdependent (Jehn, Northcraft, \& Neale, 1999). Van der Vegt and Van de Vliert (2005) also found that perceived skill dissimilarity is positively associated with helping behavior between highly task-interdependent members. Thus, this study predicts that high levels of task interdependence among group members would weaken the negative effects of demographic faultlines on group performance.

Finally, moderately task interdependent groups are 
characterized by not intense but intermittent interactions among members, which are not enough to develop open communication among members (Stewart \& Barrick, 2000). Furthermore, in contrast to high task interdependence, moderate task interdependence is not sufficient to offer norms of cooperation and need for coordination, rendering interactions less cooperative. These sporadic interactions without cooperation among members lead to the salience of subgroups in groups with demographic strong faultines.

Contact hypothesis (Allport, 1954) proposes that one of the prerequisite conditions of contact for reducing intergroup prejudice is intergroup cooperation. In accordance with the theory, Sherif et al. (1961) and Gaertner, Mann, Dovidio, Murrell, and Pomare (1990) shows that mere intergroup contact does not lead to harmonious intergroup relations, and even exacerbates the relations. Thus, when the groups with strong demographic faultlines are moderately task interdependent, the erratic interactions without cooperation cause subgroup identities, which arise from strong demographic faultlines, to become salient and, in turn, increase in-group favoritism and negative out-group stereotypes (Hornsey \& Hogg, 2000). On top of that, in contrast to those in low task interdependent groups, members in moderately task interdependent groups find it difficult to identify the individual contribution because of the diffused responsibility of members and a lack of open communication (Stewart \& Barrick, 2000). This situation increases the members' the subjective uncertainty and reinforces the social-categorization (Hogg \& Terry, 2000) and the salience of subgroups, when demographic faultlines are strong.

To sum up, when groups possess strong faultlines, sparse interactions and diffused responsibilities arising from moderate task interdependence increase the salience of subgroups and exacerbate the negative impacts of demographic faultlines on group performance. In support of the argument, Joshi and Roh (2009) found in their metaanalysis of diversity that the effects of relation-oriented diversity on group performance is most negative when task interdependence is moderate. Several studies also have documented that task interdependence has U-shaped relationship with collective performance (Saavedra et al., 1993; Stewart \& Barrick, 2000; Wageman, 1995). Thus, this study hypothesizes as follows in combination with the argument on the low, moderate, and high task interdependence and demographic faultlines.

Hypothesis 1. The negative relationship between demographic faultlines and group performance is curvilinearly moderated by task interdependence in such a way that the negative relationship between demographic faultlines and group performance is strongest when task interdependence is moderate.

\section{Research Method}

\subsection{Procedure and Sample}

The study was conducted in six organizations in Korea, their industries including 1) heavy industries, 2) hospital, 3) construction, 4) petrochemical, 5) fine chemicals, and 6) system integration. Within these six companies, the survey was distributed to 1330 individuals in 162 teams and 1082 individuals in 137 teams responded to the questionnaire, for a response rate of $81.4 \%$. Since larger subgroups do not appropriately explain subgroups, this study explains the faultlines concept using 4 to 20 individuals within a team because. Moreover, individual responses were aggregated into team-level variables with validity. Responses from individuals on teams where fewer than four members responded were eliminated to meet the minimum requirement to check inter-rater reliability (rwg) (James, Demaree, \& Wolf, 1984) and the inter-class correlation coefficient (ICC) (Shrout \& Fleiss, 1979). After removing responses based on these criteria, the study used 641 members of 82 teams for further analysis.

Table 1: Demographic Profiles of Respondents and Teams

\begin{tabular}{|c|c|c|c|}
\hline \multicolumn{2}{|c|}{ Characteristic } & Frequency & Percentage \\
\hline \multicolumn{4}{|c|}{ Individual $(\mathrm{N}=641)$} \\
\hline \multirow{2}{*}{ Gender } & Male & 459 & $71.60 \%$ \\
\hline & Female & 182 & $28.40 \%$ \\
\hline \multirow{4}{*}{ Age } & $20 \mathrm{~s}$ & 153 & $23.90 \%$ \\
\hline & $30 \mathrm{~s}$ & 243 & $37.90 \%$ \\
\hline & $40 \mathrm{~s}$ & 188 & $29.30 \%$ \\
\hline & $50 \mathrm{~s}^{+}$ & 57 & $8.90 \%$ \\
\hline \multirow{5}{*}{$\begin{array}{c}\text { Organiza- } \\
\text { tional } \\
\text { tenure }\end{array}$} & $<2$ years & 91 & $14.20 \%$ \\
\hline & $2-5$ years & 116 & $18.10 \%$ \\
\hline & $5-10$ years & 146 & $22.80 \%$ \\
\hline & $10-20$ years & 171 & $26.70 \%$ \\
\hline & $>20$ years & 117 & $18.20 \%$ \\
\hline \multicolumn{4}{|c|}{ Team $\quad(\mathrm{N}=82)$} \\
\hline \multirow{2}{*}{ Team type } & Manufacturing & 53 & $64.60 \%$ \\
\hline & Non-manufacturing & 29 & $35.40 \%$ \\
\hline \multirow{3}{*}{ Team size } & $<6$ members & 20 & $24.40 \%$ \\
\hline & $6-12$ members & 31 & $37.80 \%$ \\
\hline & $>12$ members & 31 & $37.80 \%$ \\
\hline
\end{tabular}

Table 1 shows the demographic profiles of the respondents. $459(71.6 \%)$ respondents were male and 182 $(28.4 \%)$ were female. $32.3 \%$ of respondents had less than 5 
years tenure (in their current organizations), while $22.8 \%$ of respondents had tenure between 5 to 10 years, $26.7 \%$ of respondents had tenure between 10 to 20 years, and $18.2 \%$ had tenure greater than 20 years. The average age of the respondents was 36.5 years. With regards to teams, $64.6 \%$ of teams were manufacturing team and $35.4 \%$ were nonmanufacturing such as staff.

\subsection{Measures}

All the measures were based on seven-point Likert-type scale ranging from strongly disagree (1) to strongly agree (7). Task interdependence (TI) was modified to the within team context from between team context measured using a 5-item scale adopted from Staples and Webster (2008). Group performance (GP) was measured with a 5-item scale based on Hoegl, Weinkauf, and Gemuenden (2004). Measure items are described in Table 2. The personnel records were used to locate information on employees' age, gender, and tenure within the current organization for demographic faultlines. These attributes were chosen based on prior research (Jehn, Chadwick, \& Thatcher, 1997; Jehn et al., 1999; Polzer, Milton, \& Swarm, 2002).

Table 2: Measurement Items and Factor Analysis

\begin{tabular}{|c|c|c|}
\hline Questions & $\begin{array}{c}\text { Task } \\
\text { interde- } \\
\text { pendence }\end{array}$ & $\begin{array}{c}\text { Group } \\
\text { perfor- } \\
\text { mance }\end{array}$ \\
\hline $\begin{array}{c}\text { Goal attainment for one team } \\
\text { member helps goal attainment for } \\
\text { others. }\end{array}$ & $\mathbf{. 7 6 9}$ & .386 \\
\hline $\begin{array}{c}\text { For the team to perform well, } \\
\text { members must communicate well. }\end{array}$ & $\mathbf{. 9 1 3}$ & .246 \\
\hline $\begin{array}{c}\text { To achieve high performance, it is } \\
\text { important to rely on each other. }\end{array}$ & $\mathbf{. 8 8 4}$ & .331 \\
\hline $\begin{array}{c}\text { Jobs performed by different team } \\
\text { members are related to one another. }\end{array}$ & $\mathbf{. 8 8 2}$ & .201 \\
\hline $\begin{array}{c}\text { Going by the current status, this } \\
\text { group can be regarded as successful. }\end{array}$ & .453 & $\mathbf{. 8 1 4}$ \\
\hline $\begin{array}{c}\text { So far, all group goals have been } \\
\text { achieved. }\end{array}$ & .316 & $\mathbf{. 9 0 9}$ \\
\hline $\begin{array}{c}\text { The group's output so far is of high } \\
\text { quality. }\end{array}$ & .370 & $\mathbf{. 8 9 9}$ \\
\hline $\begin{array}{c}\text { The group is satisfied with its } \\
\text { performance to this point. }\end{array}$ & .251 & $\mathbf{. 9 2 1}$ \\
\hline $\begin{array}{c}\text { The project leadership can be fully } \\
\text { satisfied with the task progress of this } \\
\text { group. }\end{array}$ & .181 & $\mathbf{. 3 5}$ \\
\hline
\end{tabular}

This study uses the faultlines algorithm established by Thatcher et al. (2003) and applied in other faultlines studies (Bezrukova, Spell, \& Perry, 2010; Lau \& Murnighan, 2005). Based on multivariate statistical clustering analysis (Morrison, 1967; Zanutto, Bezrukova, \& Jehn, 2011), the measure considers cumulative proportions of variance across attributes and assesses how well variability within the team can be portrayed by the presence of different subgroups (alignments of members on multiple attributes) within the team. As recommended by prior researchers (Bezrukova et al., 2009; Cooper, Patel, \& Thatcher, 2014), the strength of faultines splits, referred to as Fau, is calculated to designate how cleanly a team with a total of $\mathrm{n}$ members measured on $\mathrm{p}$ characteristics divides into two subgroups by calculating the percentage of total variation in overall team attributes accounted for by the strongest team split.

More precisely, this measure is produced by computing the proportion of the between-group sum of squares to the total sum of squares in a two-stage process. The first stage calculates

$$
\operatorname{Fau}_{g}=\left(\frac{\sum_{j=1}^{p} \sum_{k=1}^{2} n_{k}^{g}\left(\bar{x}_{. j k}-\bar{x}_{. j .}\right)^{2}}{\sum_{j=1}^{p} \sum_{k=1}^{2} \sum_{i=1}^{n_{k}^{g}}\left(\bar{x}_{i j k}-\bar{x}_{. j .}\right)^{2}}\right), g=1,2, \ldots, S
$$

where $x_{i j k}$ is the value of the jth attribute of the ith member of subgroup k. $\bar{x}_{. j}$. is the overall group means of attribute $\mathrm{j}, \bar{x}_{. j k}$ is the mean of attribute $\mathrm{j}$ in subgroup $\mathrm{k}$, and $n_{k}^{g}$ is the number of members of the kth subgroup (k $=1,2)$ in split $\mathrm{g}$. The second stage computes the maximum value of Faug over all possible splits $g=1,2, \ldots \mathrm{S}$. The analysis maximizes over all possible splits where each subgroup consists of at least two members, that is, the study does not consider subgroups with a single member. Fau always exists in the range from zero to one with the higher values indicating greater faultlines strength. The values of demographic faultlines strength in our dataset range from 0.488 (weak faultlines) to 0.871 (strong faultlines).

To control the other possible explanations for group performance, we included control variables such as group type, group size, and company. The analysis controls for group size since it can influence performance (Hackman \& Vidmar, 1970) and larger groups are more prone to break into subgroups (Shaw, 2004). Based on the nature of the data, the analysis includes a control for group types such as manufacturing and non-manufacturing teams.

To distinguish the unique effects of faultlines related to a particular alignment of members, the analysis controls the diversity effect as recommended by Bezrukova, Thatcher, and Jehn (2007) and Lau and Murnighan (2005). Blau (1977) heterogeneity index is used to calculate diversity for categorical variables calculated by $\mathrm{D}=-\sum P_{i}^{2}$, where $\mathrm{P}$ 
represents the fractional proportion of team members assigned to a particular cluster within a given characteristic and $i$ is the number of categories represented on a team. The study uses the standard deviation to measure diversity for continuous variables such as age and organizational tenure (Allison, 1978). Since this study calculated demographic faultlines using age, gender, and organizational tenure, their diversities were controlled. In addition, the dummy variable for controlling which group has individual subgroup to make demographic faultlines were included.

\section{Results}

\subsection{Measurement Models}

The analysis requires an aggregation of the variables for task interdependence and group performance since the unit of analysis is team level. To check the legitimacy of the variables in our sample, the analysis includes a test of the inter-rate agreement (rwg) (James et al., 1984) and interclass correlation (ICC) (Shrout \& Fleiss, 1979). These two variables exceeded the criteria, thereby validating the aggregation.

Table 3: Descriptive Statistics and Correlation Matrix

\begin{tabular}{|c|c|c|c|c|c|c|c|c|c|}
\hline & Mean & SD & (1) & (2) & (3) & (4) & (5) & (6) & (7) \\
\hline$(1)$ & 5.16 & 0.75 & & & & & & & \\
\hline$(2)$ & 10.7 & 4.45 & .01 & & & & & & \\
\hline$(3)$ & 0.17 & 0.05 & .23 & .13 & & & & & \\
\hline$(4)$ & 0.11 & 0.17 & .25 & -.07 & $.36^{*}$ & & & & \\
\hline$(5)$ & 0.61 & 0.31 & .15 & .15 & $.70^{*}$ & .21 & & & \\
\hline$(6)$ & 0.24 & 0.43 & -.07 & $-.37^{*}$ & .07 & -.06 & .08 & & \\
\hline$(7)$ & 0.68 & 0.07 & $-.44^{*}$ & -.18 & .11 & -.05 & .12 & .09 & \\
\hline$(8)$ & 5.56 & 0.62 & $.62^{*}$ & .05 & $.35^{*}$ & $.39^{*}$ & .28 & -.11 & -.26 \\
\hline
\end{tabular}

Notes. $\mathrm{N}=82 ; * \mathrm{p}<.01$.

(1) Group performance, (2) Group size, (3) Age diversity, (4) Gender dive rsity, (5) Tenure diversity, (6) Isolate subgroup, (7) Demographic faultline, (8) Task interdependence

The reliability for both constructs was checked using Cronbach's alpha and composite reliability values. The Cronbach's alpha values of task interdependence and group performance are 0.931 and 0.972 , respectively, and composite reliability values are 0.978 and 0.976 , respectively. All are greater than 0.7, thus demonstrating reliability. Factor analysis is used to assess convergent and discriminant validity. During this process, one item on task interdependence was excluded. Each factor loading is greater than 0.6 and cross-loadings are lower than the factor loading of the original constructs (see Table 2); thus, all variables satisfy convergent and discriminant validity
(Hair, Black, Babin, Anderson, \& Tatham, 2006). In addition, the average variance extracted (AVE) values are 0.829 and 0.901 , respectively. These values are greater than 0.5 and the square root of AVEs (0.910 and 0.949, respectively) are also larger than any other correlation values. Thus, the survey instruments to measure task interdependence and group performance satisfy convergent and discriminant validity (Fornell \& Larcker, 1981).

Table 3 summarizes the correlation matrix of the variables in this study. Lastly, we checked the issue of potential common method bias. Based on Liang, Saraf, $\mathrm{Hu}$, and Xue (2007)'s method, we calculated each variance explained by the constructs and by the method factor. Since the values are 0.915 and 0.063 , respectively (see Appendix A), the common method bias is not a serious concern for this study.

\subsection{Empirical Results}

To test the hypotheses including nonlinear interactions, we conducted hierarchical regression analysis (using Stata 14 ) according to the procedure outlined by Jaccard, Turrisi, and Wan (1990) and Schilke (2014). According to this procedure, we produced the variables for analysis by averaging the items for each construct, mean-centering variables for interaction, calculating the square of the moderator (task interdependence), computing two interaction terms (linear and squared product terms). The following equation depicts our research model.

$$
\begin{aligned}
& \text { Group performance } \\
& =\mathrm{a}+\mathrm{b}_{1-5} \text { company }+b_{6} \text { group type } \\
& +b_{7} \text { group size }+b_{8} \text { age diversity } \\
& +b_{9} \text { gender diversity } \\
& +b_{10} \text { tenure diversity } \\
& +b_{11} \text { isolate group } \\
& +b_{12} \text { demographic faultlines } \\
& +b_{13} \text { task inderdependence } \\
& +b_{14} \text { task interdependence squared } \\
& +b_{15} \text { demographic faultlines } \\
& \times \text { task interdependence } \\
& +b_{16} \text { demographic faultlines } \\
& \times \text { task interdependence squared }
\end{aligned}
$$

When a coefficient of the squared moderator product term (b16) is significant, it would indicate the presence of curvilinear moderation, suggesting that linear relationship between the predictor and the dependent variable is changing as a curvilinear function of the moderator.

Table 4 summarizes the regression results. Model 1 includes only control variables. Model 2 adds the direct effects of predictors. Model 3 is our main model including squared interaction terms. We conducted the variance 
inflation factors (VIF) for all explanatory variables. The highest value was 5.13, lower than 10, thus multicollinearity is not problematic (Neter, Kutner, Nachtsheim, \& Wasserman, 1996).

With regard to control variables, group type and gender diversity are positively significant for group performance, while age and tenure diversity, and isolate group are not significant for all three models. In terms of group size, it is negatively significant in Models 2 and 3. The results show that manufacturing teams have better performance than non-manufacturing teams, and teams that have a more diverse composition in gender perform better, while bigger size teams perform worse.

Regarding the base effect in Model 3, the regression coefficient of -5.400 indicates a negative and highly significant $(p<0.001)$ relationship between demographic faultlines and group performance. Hypothesis 1 stated the nonlinear moderating effect of task interdependence on the relationship between demographic faultlines and group performance. Results (shown in Model 3) highlighted that the positive coefficient of the squared interaction terms was significant, that is, the relationships between the demographic faultlines and group performance vary across different levels of task interdependence in a quadratic manner. The nature of the interaction is illustrated in Figure 1 .

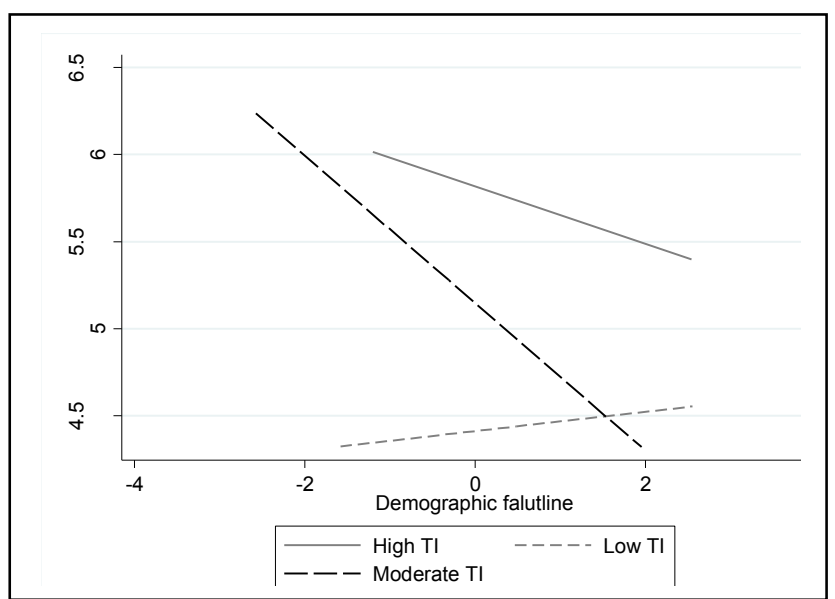

Note. $\mathrm{TI}=$ task interdependence

Figure 1: The relationship between demographic faultlines and group performance as a function of task interdependence

The proposed negative relationship between demographic faultines and group performance across increasing levels of task interdependence is apparent in the graph. As shown in Figure 1, for groups that experience a high level of task interdependence, the slope for the regression of demographic faultlines on group performance is comparatively low and, at a low level of task interdependence, insignificant (especially it seems like positive). However, at intermediate levels of task interdependence, the association was strongly negative and significant. These illustrations and the significant interaction of squared term provide empirical support for Hypothesis 1.

Table 4: Hierarchical Regression Results

\begin{tabular}{|c|c|c|c|}
\hline Variables & Model 1 & Model 2 & Model 3 \\
\hline Intercept (a) & $\begin{array}{c}4.833 * * * \\
(1.289) \\
\end{array}$ & $\begin{array}{l}3.634^{* *} \\
(1.149) \\
\end{array}$ & $\begin{array}{c}3.823 * * * \\
(0.639) \\
\end{array}$ \\
\hline \multicolumn{4}{|c|}{ Control variables } \\
\hline $\begin{array}{c}\text { Companies }\left(\mathrm{b}_{1-5}\right) \\
\text { (5 dummy variables) }\end{array}$ & \multicolumn{3}{|c|}{ Included } \\
\hline Group type $\left(b_{6}\right)$ & $\begin{array}{l}0.524^{*} \\
(0.208)\end{array}$ & $\begin{array}{l}0.504 * * \\
(0.165)\end{array}$ & $\begin{array}{l}0.550 * * \\
(0.163)\end{array}$ \\
\hline Group size $\left(b_{7}\right)$ & $\begin{array}{l}-0.033 \\
(0.024)\end{array}$ & $\begin{array}{l}-0.045^{*} \\
(0.019)\end{array}$ & $\begin{array}{c}-0.054^{* *} \\
(0.020)\end{array}$ \\
\hline Age diversity $\left(b_{8}\right)$ & $\begin{array}{c}1.609 \\
(2.588)\end{array}$ & $\begin{array}{c}0.726 \\
(2.000)\end{array}$ & $\begin{array}{c}0.555 \\
(2.069)\end{array}$ \\
\hline Gender diversity $\left(\mathrm{b}_{9}\right)$ & $\begin{array}{l}1.921 * * \\
(0.599)\end{array}$ & $\begin{array}{l}0.990^{*} \\
(0.482) \\
\end{array}$ & $\begin{array}{l}0.980^{*} \\
(0.472) \\
\end{array}$ \\
\hline $\begin{array}{l}\text { Organizational tenure } \\
\text { diversity }\left(\mathrm{b}_{10}\right)\end{array}$ & $\begin{array}{c}0.687 \\
(0.476) \\
\end{array}$ & $\begin{array}{c}0.325 \\
(0.382) \\
\end{array}$ & $\begin{array}{c}0.280 \\
(0.413) \\
\end{array}$ \\
\hline Isolate group $\left(b_{11}\right)$ & $\begin{array}{c}0.000 \\
(0.195)\end{array}$ & $\begin{array}{c}0.051 \\
(0.152)\end{array}$ & $\begin{array}{c}0.056 \\
(0.153)\end{array}$ \\
\hline \multicolumn{4}{|c|}{ Predictor } \\
\hline Demographic faultlines $\left(b_{12}\right)$ & & $\begin{array}{c}-3.298^{* *} \\
(0.919)\end{array}$ & $\begin{array}{c}-5.400 * * * \\
(1.262)\end{array}$ \\
\hline Task interdependence $\left(b_{13}\right)$ & & $\begin{array}{c}0.539 * * * \\
(0.120)\end{array}$ & $\begin{array}{c}0.596^{* * * *} \\
(0.122) \\
\end{array}$ \\
\hline $\begin{array}{l}\text { Task interdependence } \\
\text { squared }\left(\mathrm{b}_{14}\right)\end{array}$ & & & $\begin{array}{l}-0.119 \\
(0.162)\end{array}$ \\
\hline $\begin{array}{c}\text { Demographic faultlines } \\
\mathrm{x} \text { task interdependence }\left(\mathrm{b}_{15}\right)\end{array}$ & & & $\begin{array}{l}-1.260 \\
(1.414)\end{array}$ \\
\hline $\begin{array}{c}\text { Demographic faultlines } \\
\mathrm{x} \text { task interdependence } \\
\text { squared }\left(\mathrm{b}_{16}\right)\end{array}$ & & & $\begin{array}{l}4.606^{*} \\
(2.027)\end{array}$ \\
\hline R-squared & 0.300 & 0.596 & 0.638 \\
\hline Adjusted R-squared & 0.190 & 0.519 & 0.549 \\
\hline
\end{tabular}

Notes. $\mathrm{N}=82$, unstandardized coefficients and standard errors (in parenthe ses) are reported.

$* \mathrm{p}<0.05 ; * * \mathrm{p}<0.01 ; * * \mathrm{p}<0.001$

\section{Discussion and Conclusion}

This study investigated the contingent effects of characteristics of tasks on the relationship between demographic faultlines and group performance. Specifically, the study examined the curvilinearly moderating effects of task interdependence, which is one of the most important team design features (Kozlowski \& Bell, 2003; LePine, Piccolo, Jackson, Mathieu, \& Saul, 
2008). Using data on 82 groups within six firms in Korea, the study found that the negative relationship between demographic faultlines and group performance is strongest when group members moderately task interdependent. However, groups with high or low levels of task interdependence are less likely to suffer from the devastating effects of demographic faultines.

\subsection{Theoretical Implication}

This study addresses the calls for the contingent approach to diversity and faultlines (Joshi \& Roh, 2009; Thatcher \& Patel, 2011). Even though Lau and Murnighan (1998) suggested the group's task as one of the key exogenous factors that might influence the effects of demographic faultines, only a few researchers have focused on it except for studies such as Molleman (2005) and Rico et al. (2012). This study enlarges the moderator approach to faultlines by building on the literature on task interdependence and demographic faultlines and examining the curvilinearly moderating effects of task interdependence on the effects of demographic faultlines. Future research should consider other task characteristics or contingent factors, such as task autonomy or task feedback (Hackman \& Oldham, 1980; Lee, 2018), to advance our understanding of faultlines and team outcomes.

Furthermore, in accordance with the calls, van Knippenberg et al. (2004) and van Knippenberg et al. (2011) have stressed the factors that might influence the salience of subgroups in teams. The salience of subgroups in teams is especially essential in the effects of faultines because it determines the direction and the size of the effects of faultlines. In this regard, this study identifies task interdependence as a significant moderator that either strengthens or weakens subgroup salience in groups. Specifically, groups with moderate task interdependence characterized by intermittent contacts without cooperative norms are more likely to suffer from the salience of subgroup in teams. By contrast, groups with high task interdependence develop cooperative and intense contacts among members, resulting in low salience of subgroups. Groups with low task interdependence have only limited contacts among members and identifiable responsibilities, also leading to low salience of subgroups. In this regard, future researchers might benefit from investigating other factors, such as informal learning context (Song, Chang, \& Chang, 2018), which pertain to the salience of subgroups.

This study supports the unexpected findings in a metaanalysis of Joshi and Roh (2009) on diversity. In their analysis, relations-oriented diversity in low task interdependent teams was positively related to outcomes ( $\mathrm{r}$ $=.08$ ). Furthermore, teams with moderate task interdependence showed the strongest negative relationship between relation-oriented diversity and outcomes $(\mathrm{r}=-.12)$, while those with high task interdependence showed less negative relationship $(\mathrm{r}=-.04)$. This study shows that similar patterns occur also in faultlines, demonstrating the importance of the nonlinearly, or curvilinearly, moderating effects of task interdependence in diversity and faultlines research.

This study contributes to the literature on task interdependence. Researchers have found the contradictory effects of task interdependence. To illustrate, some researchers have documented that increased task interdependence leads to more opportunities for conflict (Jehn, 1995; Wilmot \& Hocker, 2001), whereas others have studied that high task interdependence facilitates cooperation and coordination (Lam \& Chin, 2004). However, a recent meta-analysis on team interdependence has found that task interdependence is positively related to task-focused and relational team functioning (Courtright et al., 2015). In this vein, this study provides not only further support to their results, but insights into research on task interdependence by examining that moderate task interdependence might be harmful to teams in specific contexts.

\subsection{Practical Implications}

A significant challenge for today's organization is to successfully manage the increased diversity in workgroups by settling down conflicts and reaping the benefits from diversity. In this regard, this study suggests that, in order to manage subgroup categorization and conflicts sparked from strong faultlines, managers should pay attention to optimal group design by carefully assigning tasks in diverse and divided groups. Thus, managers should struggle to either increase or decrease the level of task interdependence to alleviate the negative effects of demographic faultlines. These changes can be done by adjusting individual tasks and responsibilities. By making such changes, members are less likely to attend to categorical information and develop individual deep interactions or to consider categorical information less significant. This alteration in the interaction patterns would effectually reduce the negative group processes and emergent states, and, eventually, the destructive impacts of demographic faultlines in diverse teams.

\subsection{Limitation and Suggestions for Future Research}

This study has several limitations. First, the data were collected from six companies in various industries and merged the data to form a single dataset. This kind of research design is related to two problems. First of all, 
while merging data from several firms can increase generalizability, firms' idiosyncratic characteristics can be lost. The data from more diverse organizations and industries can further generalize the findings. In addition, cross-sectional design of the research also limits the study's causal interpretation. Groups are not static, but dynamic organisms in that interaction patterns among members continuously change depending on the team contexts, and member entry and exit. Thus, groups experience continuous formation and dissolution of subgroups. Researches should delve into such characteristics of faultlines and subgroups in the future.

Although this study explored the nonlinearly moderating effect of task interdependence, it is still unclear intervening processes or emergent states that might explicitly explain the interaction effects of task interdependence and demographic faultlines. The processes and states might include norms of cooperation, group climate, communication, and so forth. Future researchers could benefit from examining intermediate processes and states to better explain the relationship between demographic faultlines and group outcomes. Furthermore, this study focused on the strength of faultlines by calculating Fau (Thatcher et al., 2003), not on the actual faultlines. Given that active faultlines have stronger effects on group performance than do dormant faultlines (Thatcher \& Patel, 2012), future researchers should incorporate these aspects of dormant and active faultlines into their research.

Another future research opportunity is to consider other types of interdependence. Team design researchers have also demonstrated the importance of outcome interdependence. In a recent meta-analysis on interdependence (Courtright et al., 2015), task interdependence has a strong relationship with task-related team functioning, while outcome interdependence has a strong relationship with relational team functioning. The results of this study might reflect the results of their metaanalysis because groups with strong demographic faultlines and high task interdependence still show negative, not positive, relationship with group performance. Considering that outcome interdependence has positive impacts on relational team functioning, future researchers should consider outcomes interdependence together with task interdependence to explain the positive effects of faultlines (Rico, Sánchez-Manzanares, Antino, \& Lau, 2012).

\section{References}

Allison, P. D. (1978). Measures of inequality. American Sociological Review, 43, 865-880.

Allport, G. W. (1954). The nature of prejudice. New York, NY: Addison-Wesley.
Anderson, S. E., \& Williams, L. J. (1996). Interpersonal, job, and individual factors related to helping processes at work. Journal of Applied Psychology, 81(3), 282-296.

Bezrukova, K., Jehn, K. A., Zanutto, E. L., \& Thatcher, S. M. (2009). Do workgroup faultlines help or hurt? A moderated model of faultlines, team identification, and group performance. Organization Science, 20(1), 35-50.

Bezrukova, K., Spell, C. S., \& Perry, J. L. (2010). Violent splits or healthy divides? Coping with injustice through faultlines. Personnel Psychology, 63(3), 719-751.

Bezrukova, K., Thatcher, S. M., \& Jehn, K. A. (2007). Group heterogeneity and faultlines: Comparing alignment and dispersion theories of group composition. In K. J. Behfar \& L. L. Thompson (Eds.), Conflict in organizational groups: New directions in theory and practice (pp. 57-92). Evanston, IL: The Northwestern University Press.

Blau, P. (1977). Inequality and composition: A primitive theory of social structure. New York, NY: Free Press.

Campion, M. A., Medsker, G. J., \& Higgs, A. C. (1993). Relations between work group characteristics and effectiveness: Implications for designing effective work groups. Personnel Psychology, 46(4), 823-847.

Cooper, D., Patel, P. C., \& Thatcher, S. M. (2014). It depends: Environmental context and the effects of faultlines on top management team performance. Organization Science, 25(2), 633-652.

Courtright, S. H., Thurgood, G. R., Stewart, G. L., \& Pierotti, A. J (2015). Structural interdependence in teams: An integrative framework and meta-analysis. Journal of Applied Psychology, 100(6), 1825-1846.

Cronin, M. A., Bezrukova, K., Weingart, L. R., \& Tinsley, C. H. (2011). Subgroups within a team: The role of cognitive and affective integration. Journal of Organizational Behavior, 32(6), 831-849.

Fornell, C., \& Larcker, D. F. (1981). Evaluating structural equation models with unobservable variables and measurement error. Journal of Marketing Research, 18(1), 3950 .

Gaertner, S. L., Dovidio, J. F., Anastasio, P. A., Bachman, B. A., \& Rust, M. C. (1993). The common ingroup identity model: Recategorization and the reduction of intergroup bias. European Review of Social Psychology, 4(1), 1-26.

Gaertner, S. L., Mann, J., Murrell, A., \& Dovidio, J. F. (1989). Reducing intergroup bias: The benefits of recategorization. Journal of Personality and Social Psychology, 57(2), 239-249.

Gaertner, S. L., Mann, J. A., Dovidio, J. F., Murrell, A. J., \& Pomare, M. (1990). How does cooperation reduce intergroup bias? Journal of Personality and Social Psychology, 59(4), 692-704.

Gibson, C. (1999). Do they do what they believe they can? Group efficacy and group effectiveness across tasks and cultures. Academy of Management Journal, 42(2), 138-152.

Gibson, C., \& Vermeulen, F. (2003). A healthy divide: Subgroups as a stimulus for team learning behavior. Administrative Science Quarterly, 48(2), 202-239.

Guzzo, R. A., \& Shea, G. P. (1992). Group performance and intergroup relations in organizations. Handbook of Industrial and Organizational Psychology, 3, 269-313.

Hackman, J. R., \& Vidmar, N. (1970). Effects of size and task 
type on group performance and member reactions. Sociometry, $33,37-54$.

Hackman, J., \& Oldham, G. (1980). Work design in the organizational context. In B. Staw \& L. Cummings (Eds.), Research in Organizational Behavior (pp.247-278), Greenwich, CT: JAI Press.

Hair, J. F., Black, W. C., Babin, B. J., Anderson, R. E., \& Tatham, R. L. (2006). Multivariate data analysis (Vol. 6). Upper Saddle River, NJ: Pearson Prentice Hall.

Hoegl, M., Weinkauf, K., \& Gemuenden, H. G. (2004). Interteam Coordination, Project Commitment, and Teamwork in Multiteam R\&D Projects: A Longitudinal Study. Organization Science, 15(1), 38-55

Hogg, M. A., \& Terry, D. I. (2000). Social identity and selfcategorization processes in organizational contexts. Academy of Management Review, 25(1), 121-140.

Homan, A. C., Hollenbeck, J. R., Humphrey, S. E., van Knippenberg, D., Ilgen, D. R., \& van Kleef, G. A. (2008). Facing differences with an open mind: Openness to experience, salience of intragroup differences, and performance of diverse work groups. Academy of Management Journal, 51(6), 1204-1222.

Hornsey, M. J., \& Hogg, M. A. (2000). Assimilation and diversity: An integrative model of subgroup relations. Personality and Social Psychology Review, 4(2), 143-156.

Jaccard, J., Turrisi, R., \& Wan, C. K. 1990. Interaction effects in multiple regression. Sage University Paper series on quantitative applications in the social sciences, 07-069. Newbury Park, CA: Sage.

James, L. R., Demaree, R. G., \& Wolf, G. (1984). Estimating Within-Group Interrater Reliability with and without Response Bias. Journal of Applied Psychology, 69(1), 85-98.

Jehn, K. A. (1995). A multimethod examination of the benefits and detriments of intragroup conflict. Administrative Science Quarterly, 40(2), 256-282.

Jehn, K. A., \& Bezrukova, K. (2010). The faultline activation process and the effects of activated faultlines on coalition formation, conflict, and group outcomes. Organizational Behavior and Human Decision Processes, 112(1), 24-42.

Jehn, K. A., Chadwick, C., \& Thatcher, S. M. (1997). To agree or not to agree: The effects of value congruence, individual demographic dissimilarity, and conflict on workgroup outcomes. International Journal of Conflict Management, 8(4), 287-305.

Jehn, K. A., Northcraft, G. B., \& Neale, M. A. (1999). Why differences make a difference: A field study of diversity, conflict and performance in workgroups. Administrative Science Quarterly, 44(4), 741-763.

Johnson, D. W., \& Johnson, R. T. (1989). Cooperation and competition: Theory and research. Edina, MN: Interaction Book Company.

Joshi, A., \& Roh, H. (2009). The role of context in work team diversity research: A meta-analytic review. Academy of Management Journal, 52(3), 599-627.

Kiggundu, M. N. (1983). Task interdependence and job design: Test of a theory. Organizational Behavior and Human Performance, 31(2), 145-172.

Kozlowski, S. W., \& Bell, B. S. (2003). Work groups and teams in organizations. In W. C. Borman \& D. R. Ilgen (Eds.),
Handbook of psychology: Industrial and organizational psychology (Vol. 12, pp. 333-375). New York, NY: Wiley.

Lam, P. K., \& Chin, K. S. (2004). Project factors influencing conflict intensity and handling styles in collaborative NPD. Creativity and Innovation Management, 13(1), 52-62.

Lau, D. C., \& Murnighan, J. K. (1998). Demographic diversity and faultines: The compositional dynamics of organizational groups. Academy of Management Review, 23(2), 325-340.

Lau, D. C., \& Murnighan, J. K. (2005). Interactions within groups and subgroups: The effects of demographic faultlines. Academy of Management Journal, 48(4), 645-659.

Lee, J. Y. (2018). The effects of job characteristics on the team creativity of distribution companies: Moderating effects of transformational leadership. Journal of Asian Finance, Economics and Business, 5(4), 161-172. http://doi.org/10.13106/jafeb.2018.vol5.no4.161

LePine, J. A., Piccolo, R. F., Jackson, C. L., Mathieu, J. E., \& Saul, J. R. (2008). A meta-analysis of teamwork processes: tests of a multidimensional model and relationships with team effectiveness criteria. Personnel Psychology, 61(2), 273-307.

Li, J., \& Hambrick, D. C. (2005). Factional groups: A new vantage on demographic faultines, conflict, and disintegration in work teams. Academy of Management Journal, 48(5), 794-813.

Liang, H., Saraf, N., Hu, Q., \& Xue, Y. (2007). Assimilation of enterprise dystems: The effects of institutional pressures and the mediating role of top management. MIS Quarterly, 31(1), 59-88.

Molleman, E. (2005). Diversity in demographic characteristics, abilities and personality traits: Do faultlines affect team functioning? Group Decision and Negotiation, 14(3), 173-193.

Morrison, D. G. (1967). Measurement problems in cluster analysis. Management Science, 13(12), B775-B780.

Na, D. M., Park, S. H., \& Kwak, W. J. (2018). The demographic faultine is a new situational factor for team management: The effect of leader teamwork behaviors on support for innovation. Journal of Asian Finance Economics and Business, 5(4), 149160. http://doi.org/10.13106/jafeb.2018.vol5.no4.149

Neter, J., Kutner, M. H., Nachtsheim, C. J., \& Wasserman, W. (1996). Applied linear statistical models. Boston, MA: McGraw-Hill.

O'Reilly III, C. A., Caldwell, D. F., \& Barnett, W. P. (1989). Work group demography, social integration, and turnover. Administrative Science Quarterly, 34(1), 21-37.

Pearce, J. L., \& Gregersen, H. B. (1991). Task interdependence and extrarole behavior: A test of the mediating effects of felt responsibility. Journal of Applied Psychology, 76(6), 838-844.

Pettigrew, T. F. (1998). Intergroup contact theory. Annual Review of Psychology, 49(1), 65-85.

Polzer, J. T., Milton, L. P., \& Swarm, W. B. (2002). Capitalizing on diversity: Interpersonal congruence in small work groups. Administrative Science Quarterly, 47(2), 296-324.

Rico, R., Molleman, E., Sánchez-Manzanares, M., \& Van der Vegt, G. S. (2007). The effects of diversity faultlines and team task autonomy on decision quality and social integration. Journal of Management, 33(1), 111-132.

Rico, R., Sánchez-Manzanares, M., Antino, M., \& Lau, D. (2012). Bridging team faultlines by combining task role assignment and goal structure strategies. Journal of Applied Psychology, 
97(2), 407-420.

Saavedra, R., Earley, P. C., \& Van Dyne, L. (1993). Complex interdependence in task-performing groups. Journal of Applied Psychology, 78(1), 61-72.

Schilke, O. (2014). On the contingent value of dynamic capabilities for competitive advantage: The nonlinear moderating effect of environmental dynamism. Strategic Management Journal, 35(2), 179-203.

Shaw, J. B. (2004). The development and analysis of a measure of group faultines. Organizational Research Methods, 7(1), 66100.

Shaw, M. E. (1981). Group dynamics: The psychology of small group behavior. New York, NY: McGraw-Hill

Sherif, M., Harvey, O., White, B., Hood, W., \& Sherif, C. (1961). Intergroup conflict and cooperation: The Robbers Cave experiment: Norman, OK: University of Oklahoma.

Shrout, P. E., \& Fleiss, J. L. (1979). Intraclass Correlations: Uses in Assessing Rater Reliability Psychological Bulletin, 86(2), 420-428.

Song, Y., Chang, W., \& Chang, J. (2018). The effective factors of professional learning: Study on accounting firms in Korea. Journal of Asian Finance, Economics and Business, 5(2), 8194. https://doi.org/10.13106/jafeb.2018.vol5.no2.81

Staples, D. S., \& Webster, J. (2008). Exploring the effects of trust, task interdependence and virtualness on knowledge sharing in teams. Information Systems Journal, 18(6), 617-640.

Stewart, G. L., \& Barrick, M. R. (2000). Team structure and performance: Assessing the mediating role of intrateam process and the moderating role of task type. Academy of Management Journal, 43(2), 135-148.

Tajfel, H. (1978) The achievement of group differentiation. In H. Tajfel (Ed.), Differentiation between social groups: Studies in the social psychology of intergroup relations (pp. 77-98). Cambridge, MA: Academic Press.

Thatcher, S. M., Jehn, K. A., \& Zanutto, E. (2003). Cracks in diversity research: The effects of diversity faultlines on conflict and performance. Group Decision and Negotiation, 12(3), 217-241.
Thatcher, S. M., \& Patel, P. C. (2011). Demographic faultlines: a meta-analysis of the literature. Journal of Applied Psychology, 96(6), 1119-1139.

Thatcher, S. M., \& Patel, P. C. (2012). Group faultlines a review, integration, and guide to future research. Journal of Management, 38(4), 969-1009.

Thompson, J. D. (1967). Organizations in action: Social science bases of administrative theory. Piscataway, NJ: Transaction Publishers.

Turner, J. C. (1982). Towards a cognitive redefinition of the social group. In H. Tajfel (Ed.), Social Identity and Intergroup Relations (pp.15-40). Cambridge, England: Cambridge University Press

Turner, J. C., Hogg, M. A., Oakes, P. J., Reicher, S. D., \& Wetherell, M. S. (1987). Rediscovering the social group: A self-categorization theory. Hoboken, NJ: Basil Blackwell.

Van der Vegt, G. S., \& Janssen, O. (2003). Joint impact of interdependence and group diversity on innovation. Journal of Management, 29(5), 729-751.

Van der Vegt, G. S., \& Van de Vliert, E. (2005). Effects of perceived skill dissimilarity and task interdependence on helping in work teams. Journal of Management, 31(1), 73-89.

van Knippenberg, D., Dawson, J. F., West, M. A., \& Homan, A. C. (2011). Diversity faultlines, shared objectives, and top management team performance. Human Relations, 64(3), 307-336.

van Knippenberg, D., De Dreu, C. K., \& Homan, A. C. (2004). Work group diversity and group performance: an integrative model and research agenda. Journal of Applied Psychology, 89(6), 1008-1022.

Wageman, R. (1995). Interdependence and group effectiveness. Administrative Science Quarterly, 40(1), 145-180.

Wilmot, W. W., \& Hocker, J. L. (2001). Interpersonal conflict. New York, NY: McGraw-Hill.

Zanutto, E. L., Bezrukova, K., \& Jehn, K. A. (2011). Revisiting faultline conceptualization: Measuring faultline strength and distance. Quality \& Quantity, 45(3), 701-714. 
Appendix A: Common method bias

\begin{tabular}{|c|c|c|c|c|}
\hline Item & $\begin{array}{c}\text { Factor loading on } \\
\text { construct (R1) }\end{array}$ & $\mathbf{R 1}^{\mathbf{2}}$ & $\begin{array}{c}\text { Factor loading on method } \\
\text { (R2) }\end{array}$ & $\mathbf{R 2}^{2}$ \\
\hline DF & 1.000 & 1.000 & 0.000 & 0.000 \\
\hline TI1 & 0.768 & 0.590 & 0.070 & 0.005 \\
\hline TI2 & 0.983 & 0.966 & -0.044 & 0.002 \\
\hline TI3 & 0.897 & 0.805 & 0.053 & 0.005 \\
\hline TI4 & 0.966 & 0.933 & -0.073 & 0.326 \\
\hline GP1 & 0.370 & 0.137 & 0.571 & 0.001 \\
\hline GP2 & 0.920 & 0.846 & 0.025 & 0.014 \\
\hline GP3 & 0.843 & 0.711 & 0.119 & 0.102 \\
\hline GP4 & 1.212 & 1.469 & -0.320 & 0.170 \\
\hline GP5 & 1.301 & 1.693 & -0.412 & 0.063 \\
\hline Average & & 0.915 & & \\
\hline
\end{tabular}

